\title{
Swertia chirayita in Nepal Himalayas: Cultivation and Cross Border Trade to China
}

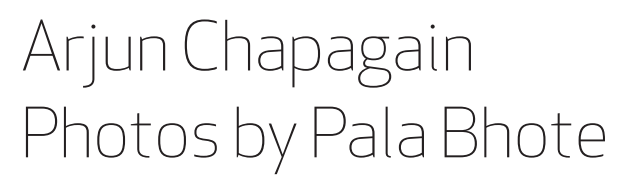

For ethnic inhabitants in the rural areas, medicinal plants are not only the cultural, sacred medicinal ingredients of traditional medicine, part of traditional belief and biodiversity but also an important cash crop to support their livelihood. With the commercialization of traditional medicine and medicinal plant-based industries worldwide, Nepalese medicinal plants are in high demand. This photo essay presents the various steps from the cultivation to the cross-border trade of Swertia chirayita (Roxb.) H. Karst., a traditional valuable medicinal plant, and a beautiful landscape of Nepal-China border. The essay contains fourteen photographs each described with captions in detail with the information collected during field work. The ethnographic study on cross border trade of medicinal plants was conducted in 2020 at Bhotkhola routes in the northeastern Nepal. Bhotkhola-Tibet border control in 2008 has politically ruptured the original link of traditional exchange among people, goods, and ideas by displacing the community from its everyday borderlands. However, the cross border trade is performed by traditional networks of Bhotiya communities such as rural ethnic inhabitants, farmers, small budget dealers, and traditional practitioners through formal and informal supply chains. The government authorities from both the countries are responsible for regulating, monitoring, and permitting medicinal plants supply from harvesters to cross-border traders.

Keywords: Bhotiya; Medicinal Plant; Nepal-China border; Supply chain. 
Swertia chirayita (Roxb.) H. Karst. (Chiraito in Nepali; Tigta in Tibetan) is among the most valuable medicinal plant species in Nepal, which scatters along the Himalayas from 1,200 to 3,000 meters above sea level (m.a.s.l.)(Cunningham et al. 2018; Phobo \& Jha 2010). It is used as an important ingredient in Ayurvedic, Unani, Tibetan and Chinese traditional medicines. It is exported in the forms of dried whole plant, (and re-exported even in the forms of extract), from Nepal to India to Europe, and the cross-Himalayan trade from Nepal to China (Phobo \& Jha 2010; 2014; He et al. 2018).

Bhotiya ethnics are Tibetan-speaking Buddhists in Nepal, popularized during the expansion of British Empire from Bengal, via Nepal, to the western Himalayan in the eighteen and nineteenth centuries (Bergmann, 2016). The Arun River (Arun in Nepali; Bum-chu in Tibetan; Pum Qu in Chinese), originated from Tibet (Bhot) runs through the district crossing the southern plains of Nepal to Indian Ganga river, has facilitated the socio-economic exchange between the Tibet and Nepal in the eastern Himalayas for hundreds of years. With the promulgation of constitution of Nepal 2015, these Bhotiya villages in the north of Sankhuwasabha district, bordered to Dinggy County of Tibet was restructured and renamed as Bhotkhola Rural Municipality meaning the region of river originated from Tibet with Bhotiya settlements.

Bhotiya ethnics practice a hybrid trans-Himalayan identity that mixes cultural elements from Tibet (language, culture, and traditions) and a political sense of Nepalese citizen. In the past, the Bhotkhola area was mostly famous for the farming of buckwheat, a popular food grain in the region. No permissions were required to use the forest resources for timber and non-timber products, particularly medicinal and food plants, until the establishment of national park and forest offices after the 1980s. Before 2008 until China tightened its border, Nepalese Bhotiya used to travel freely up to Ri'og, the nearest border market at Dinggy county of Tibet. They used to travel in groups, crossing the high mountains for about six walking days, carrying flour of buckwheat, millet, medicinal plants, and other agricultural goods and forest products on their back to reach the Ri'og. They also had to carry the food and cooking utensils for an entire trip and used to stay nights in sheds. They spent one or two days in exchanging, (selling and buying), their products, meeting friends and relatives, touring the city, and returning with salt, tea, and animal products like yak tails and sheep wools down the mountains in three days. With the construction of roads from the Chinese side, the border market shifted to Chentang, just few hours walk from Bhotkhola.
With the introduction of chemical fertilizers from Tibet, Bhotiya today? cultivate rice, maize, and millet, almost replacing buckwheat. They make a living on growing high elevation agriculture, medicinal plants, and cardamom which they trade across border markets, providing services to tourism on Makalu Barun National Park, or by working as wage labour on a number of construction sites for road, bridge, and hydropower projects (Lewis 2010). Many have migrated to the neighboring towns on their journey for livelihood opportunities and education.

Thanks to the knowledge on medicinal plants that has been passed on from generation to generation, Bhotiya have mastered the skills to locate, identify, and harvest the right part of plants at the right season, as well as post-harvest treatment (e.g. antitoxic), medicine preparation, and prescription. For them, the value of local medicinal plants moves far beyond the medical utility, but are ritually sacred, as the effectiveness of the medicine is believed to rely on the purity of the medicinal ingredients (Lewis 2010). The collection and trade of medicinal plants is controlled and regulated by state actors, they are highly in demand across the border in Chinese market. Aided by NGOs, few Bhotiyas have started cultivating valuable plants like Swertiya chitayito and Paris polyphylla, whereas most Bhotiyas following the more conventional way of collecting medicinal plants from forest. In the present essay, we aim to show the various steps from the cultivation to the cross-border trade of Swertia chirayita, an important medicinal herb in the region, through one of the ancient trans-Himalayan salt-grain trade route via NepalChina cross-border in the northeastern Nepal. 


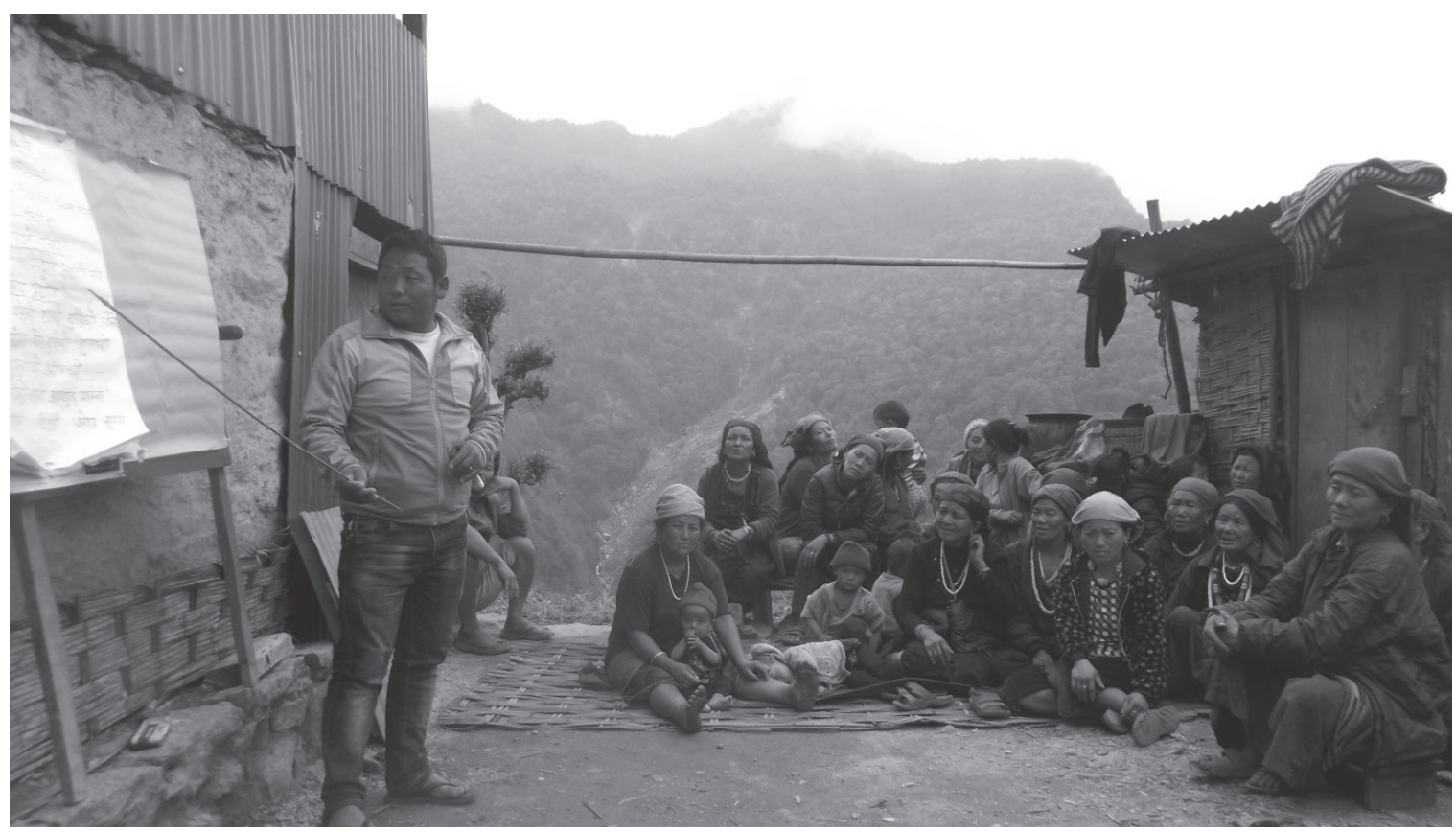

Figure 1: Theoretical training for local Bhotiya in Bhotkhola about the basic techniques of cultivation, harvesting and handling of Swertia chiarayita. The Upper Arun Valley Development and Conservation Society (UAVDCS) with the support from donor organization The Mountain Institute (TMI) Nepal trains and supports the local people at Makalu Rural Municipality and Bhotkhola Rural Municipality of Sankhuwasabha district to cultivate medicinal plants like Swertia chiarayita, Paris polyphylla, etc. The training is beneficial for local Bhotiya farmers as the local government - the sector Forest Office or Range Office of Makalu Barun National Parks and Buffer Zone (MBNPBZ)-rarely does so. Local people shared that the training is also beneficial to understand the confusing policies on medicinal plant cultivation, harvest, trade, and export for the layman.

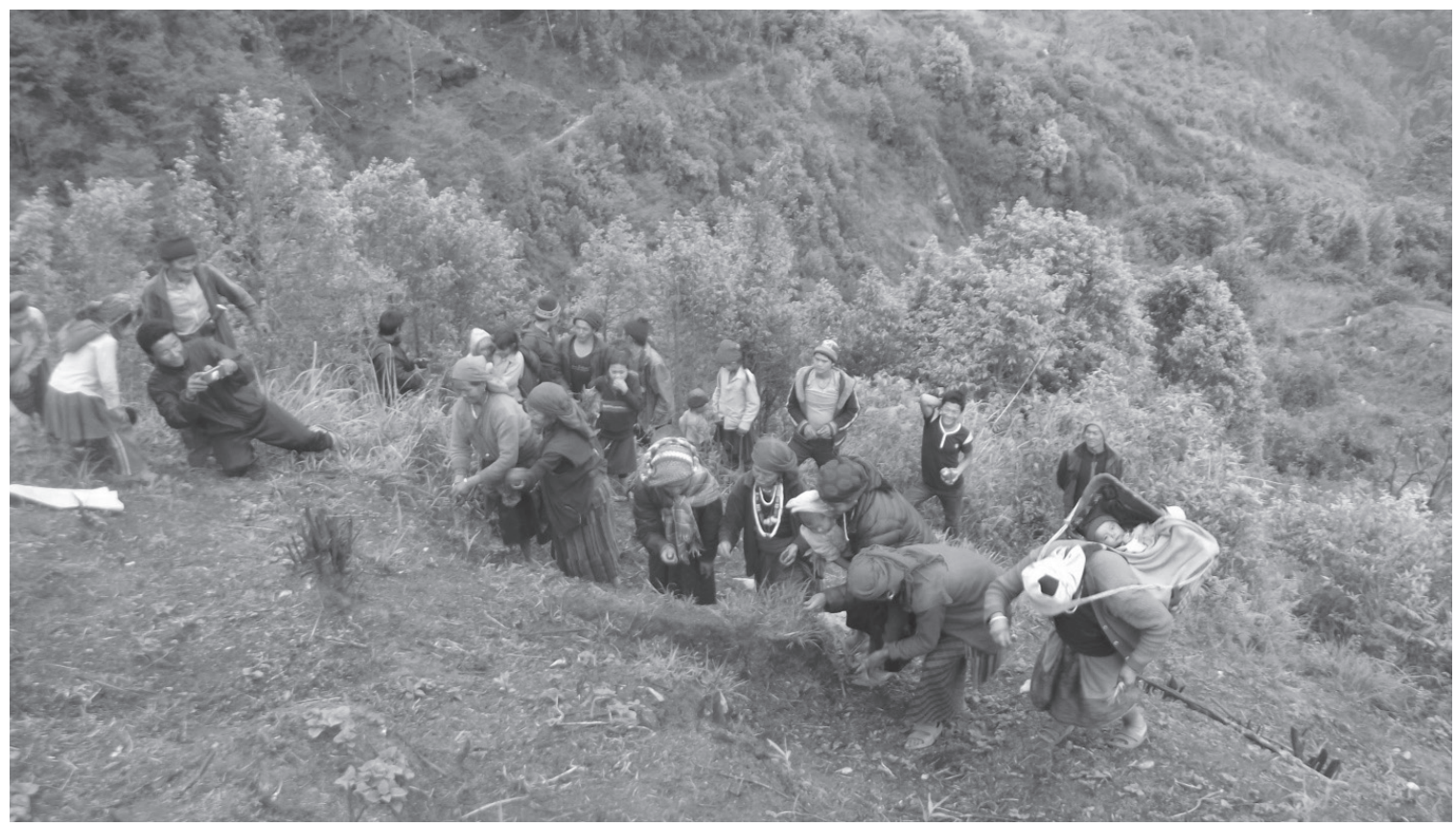

Figure 2: Practical training on field for local Bhotiya famers in Bhotkhola regarding the proper spacing and cultivation of Swertia chiarayita by UAVDCS. Land is prepared for cultivation by felling trees and even burning them. If additional manure, (green/organic or chemical fertilizer), is provided in barley growing fields, there is good production. And, if seeds are sown while harvesting millet, there is the chance of destruction by wildlife. 


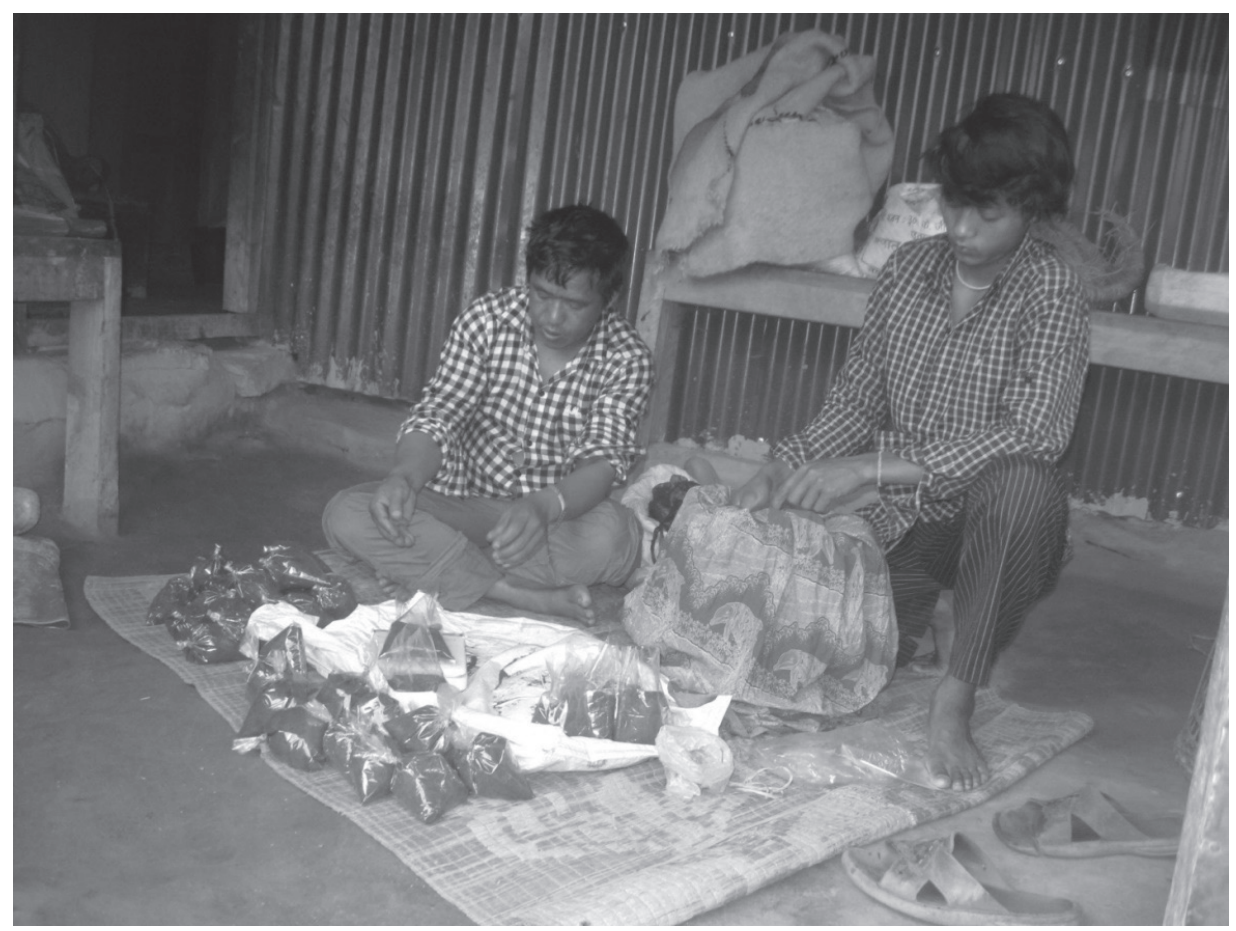

Figure 3: Packets of seeds of Swertia chiarayita ready for distribution by UAVDCS to local Bhotiyas in Bhotkhola Rural Municipality. Each packet of $200 \mathrm{~g}$ will be provided to trainees per households for three years. S. chiarayita is a perennial medicinal plant and can be harvested only every third year. So, the farmers are trained to have three different plots for three years that can be rotated, and they can have their own seeds from the fourth year onwards. UAVCDS buys the seeds from the local Bhotiya farmers for training and distributing to other local villages. In general, for every 5,476 square feet of land (one ropani), about half kilograms of seeds is needed.

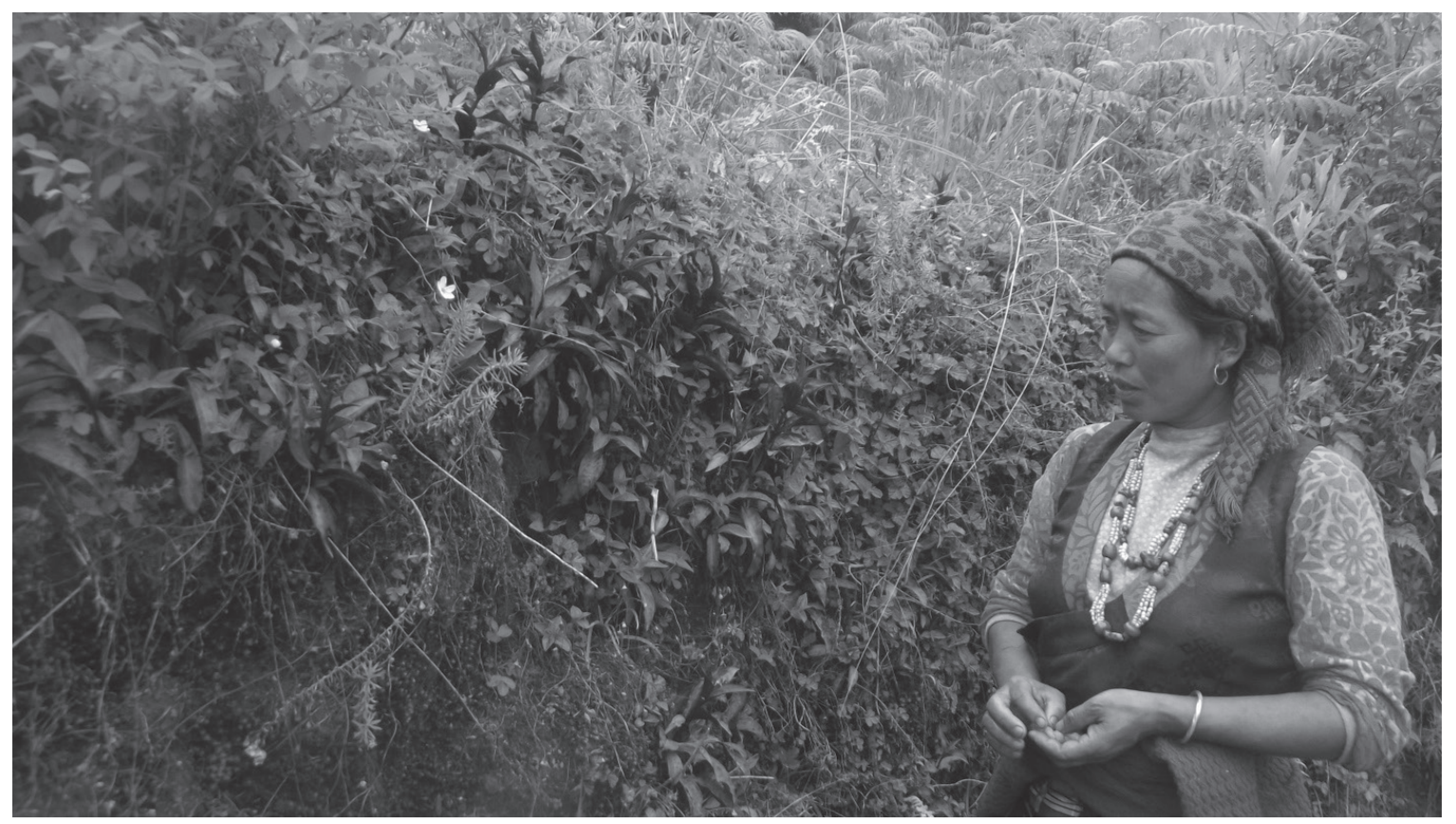

Figure 4: A local Bhotiya women observing the growth of Swertia chiarayita. The three year cultivation training has in the first year: seed dispersal and hoe (weeding) in six months. In the second year: hoe (weeding) in one and a half year, hoe in April-May (Chaitra-Baisakh). In the third year: whole matured two and a half years old plants are harvested in cloth or tent so that seeds fall itself and are collected. 


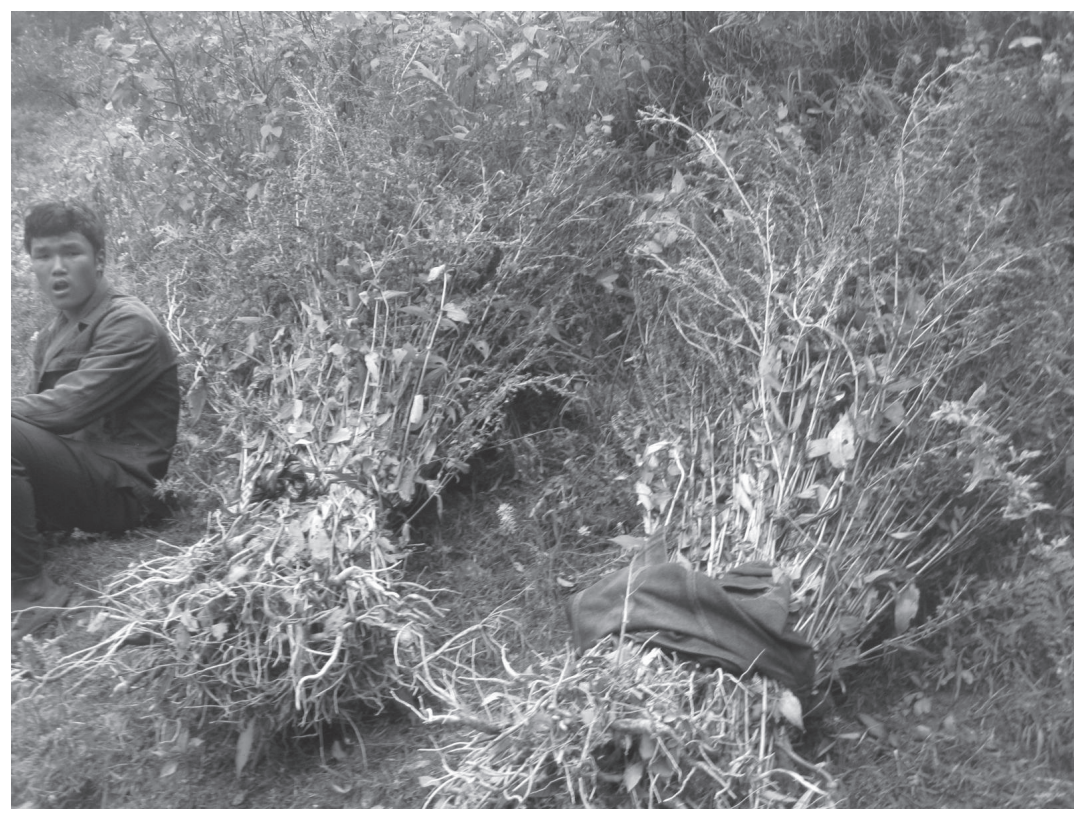

Figure 5: A local Bhotiya farmer bringing bundle of harvested Swertia chiarayita to dry and store. If production is good, in 5,476 square feet (i.e. 1 Ropani), forty to sixty kilograms can be harvested. Landless people in the area can collect medicinal plants from community forest, paying an annual 500 Nepalese currency to buffer the community forest. In registered land, the community forest and range office of MBNPBZ gives permit letters for chiraito cultivation, harvest, and trade according to registered land plot number.

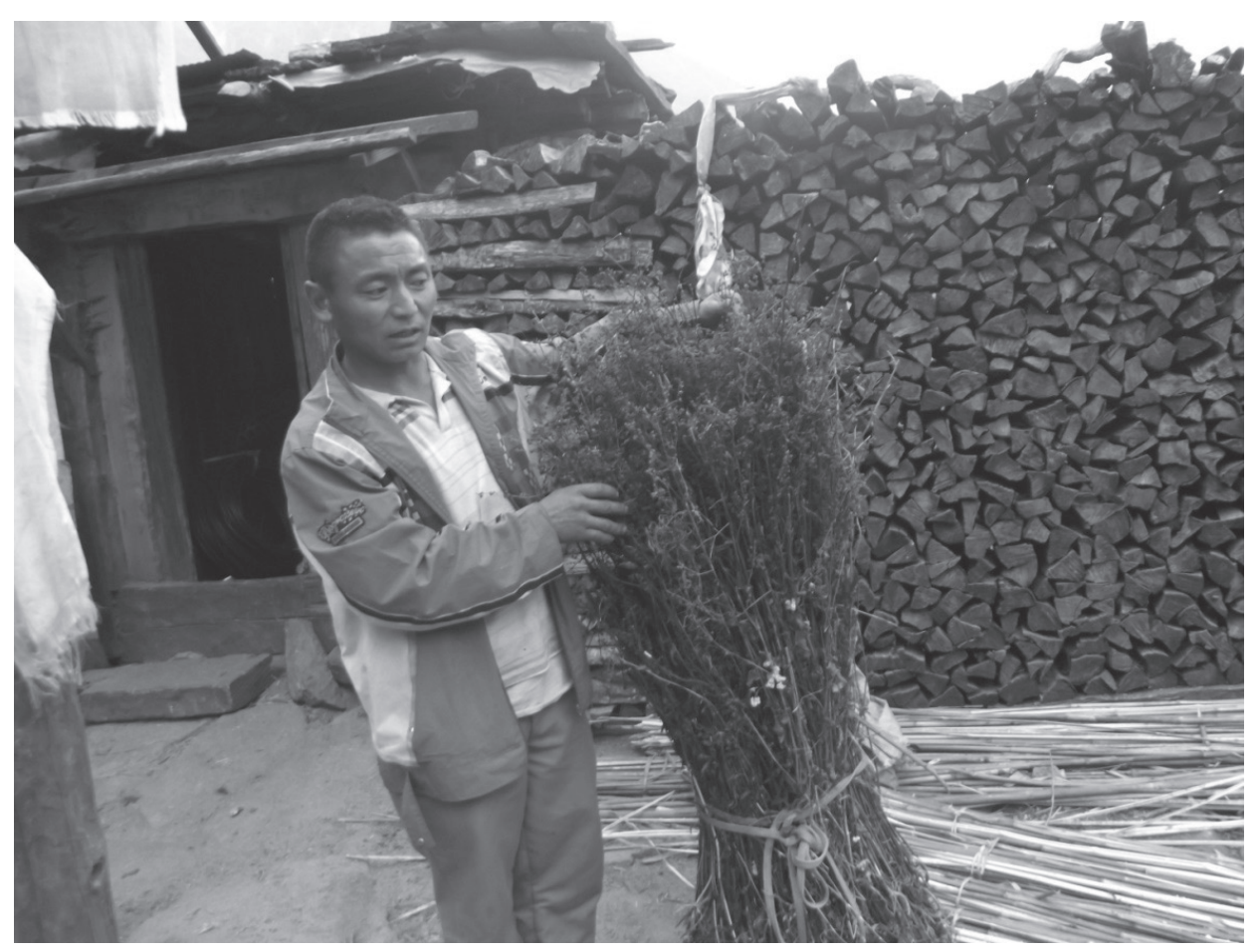

Figure 6: A local Bhotiya farmer showing a bundle of dried S. chiarayita. During the field study the average price was Nepalese currency 25000 (USD 215) per forty $\mathrm{kg}$. The money gained from trading s. chiarayita is utilized for household expenses, clothes, and school education of children. Bhotiya farmers have experienced the fluctuation of prices, maybe due to 1) less demand of previous years stock, 2) over production, 3) low quality by mixing other species of swertia, or 4) use of chemical fertilizers and pesticides as the cultivated plant has lower pharmaceutical property compared to that of wild and organic manures. 


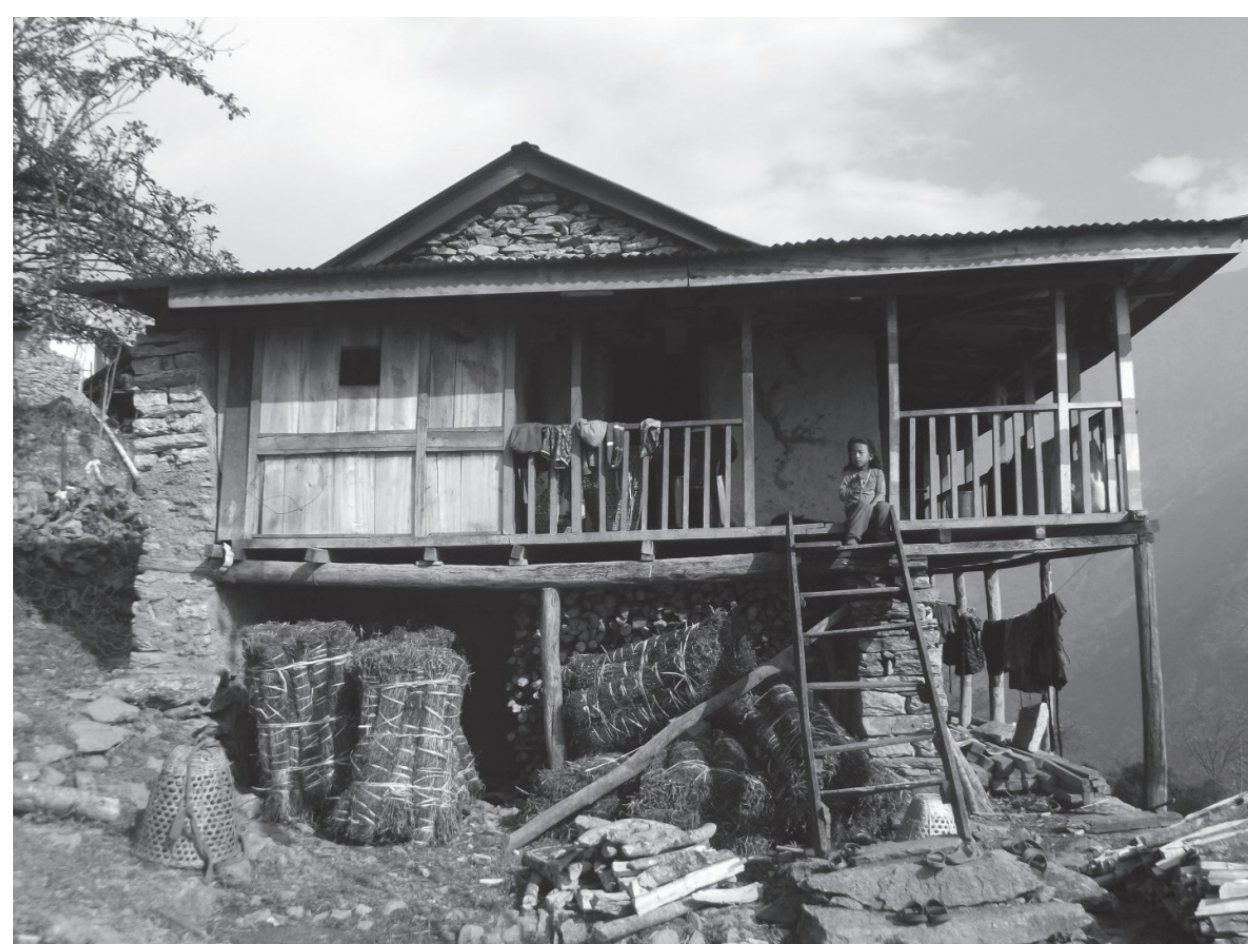

Figure 7: Bundles of packed s. chiarayita stored in a house of a farmer in Bhotkhola, ready to sell. Usually, the Tibetan/Chinese traders give an advance to Bhotiya traders of Bhotkhola for ordering a certain volume, with whole plant trade part, no collection method is shared, eg. collection of matured plant after seed fall etc. And further, Bhotiya traders give certain percent advance ordering certain volume to village level traders, usually a key person in each village. The village traders ask the locals to provide them with tigta, the local name for $S$. chiarayita, that a layman can easily understand and collect in the village or from nearby forests in the quantities ordered to them. The advance amount is given in cash in Nepalese currency, as there are no banks in the Bhotiya villages.

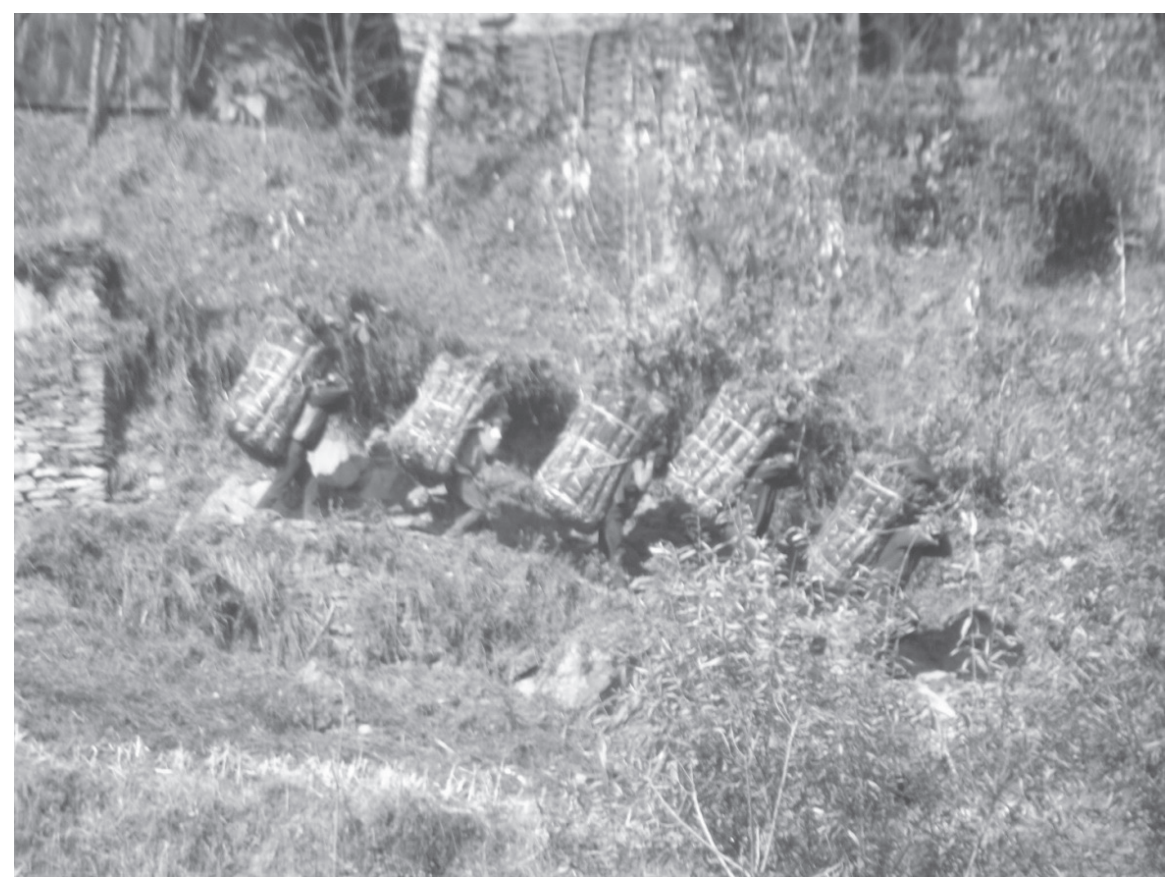

Figure 8: Bundles of dried and packed Swertia chiarayita carried in back by farmers and porters to Kimathanka-Chentang border market. 


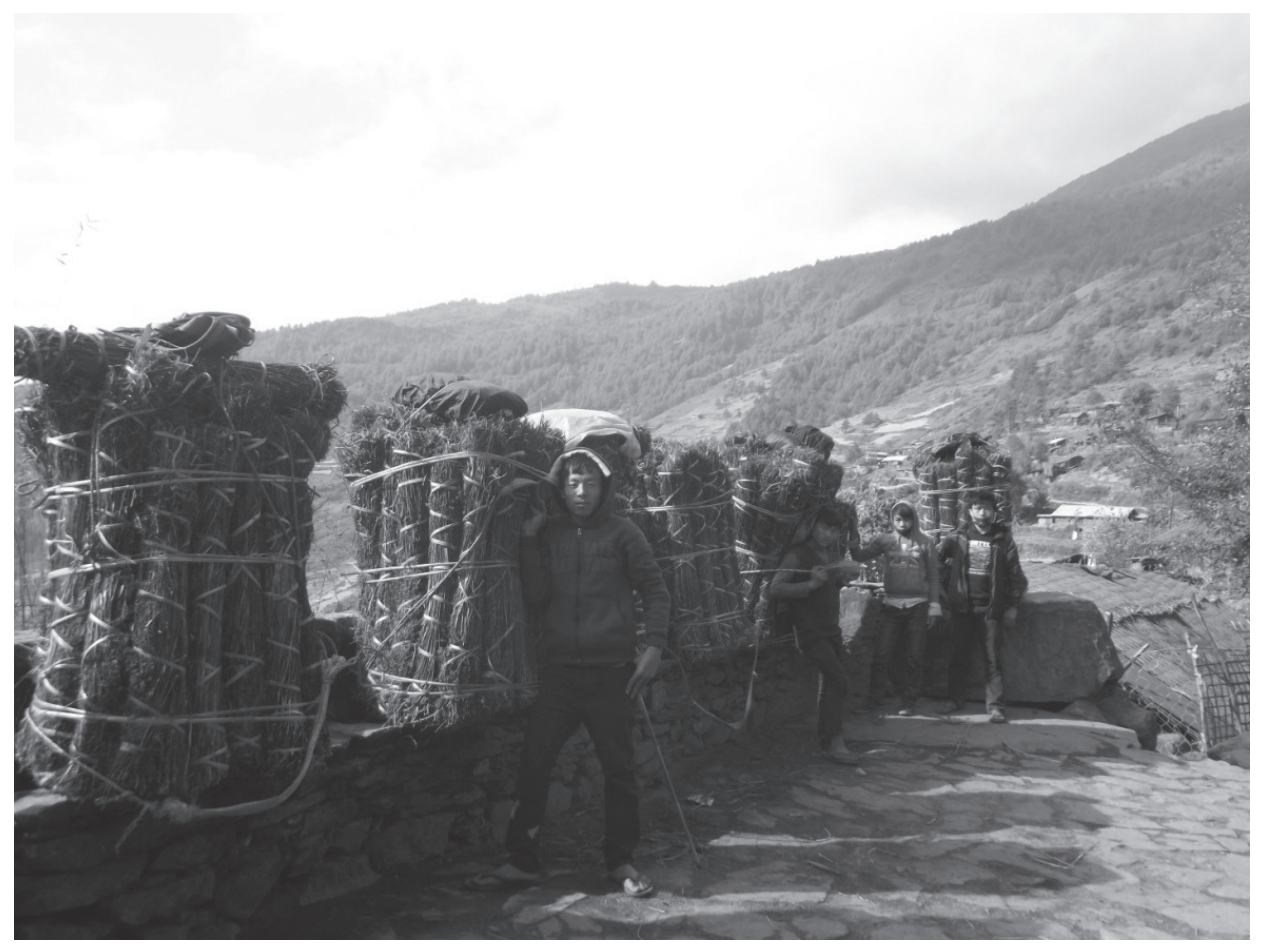

Figure 9: Bundles of dried and packed Swertia chiarayita carried in back by farmers and porters in Bhotkhola Rural Municipality.

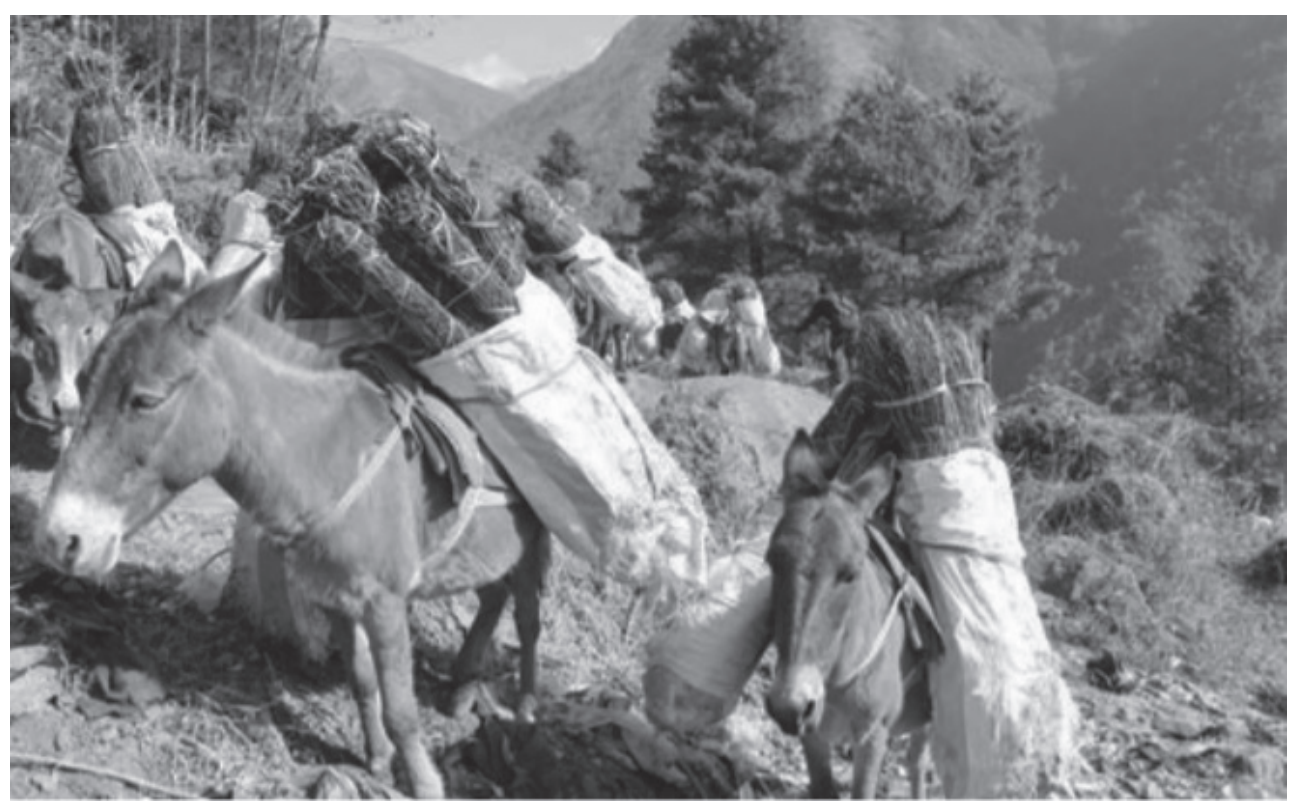

Figure 10: Bundles of dried and packed Swertia chiarayita carried by mules to transport and sell in Bhotkhola Rural Municipality. Photo Source: TM (2016). ๑ K. Bhutia. 


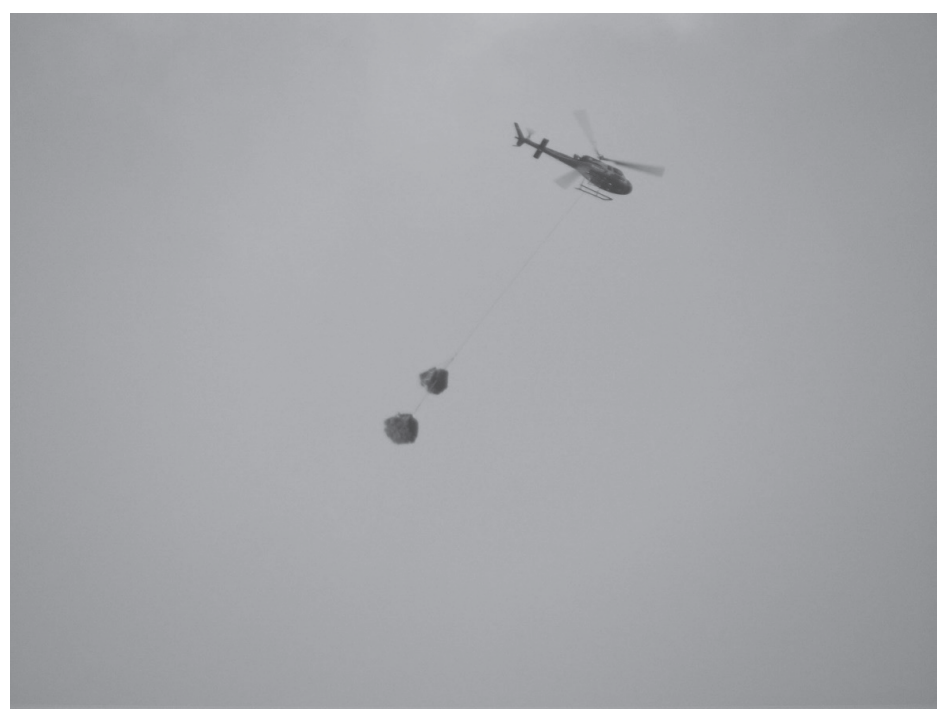

Figure 11: Bundles of dried and packed Swertia chiarayita transported by helicopter from Bhotkhola to export in Changa Bazar, Tibet, and China. Though Khandbari, the district headquarter can be reached within a day. Traders prefer to sell to Tibet as Chinese trader offers less value. For instance, present value of Swertia chiarayita at Chentang (Tibet) is Nepalese currency 23,000-25,000 up to 30,000 per $40 \mathrm{~kg}$ while that in India border is only NRs 11,000-12,000 per 40 KG. S. chiarayita from Bhotkhola, Num (Makalu RM), Khandbari Municipality, Chainpur, Mude of the southern Sankhuwasabha district, and Basantapur of the Terathum district are exported to Tibet to via this route. Bhotiya traders sell in Changa Bazaar and Chentang, where Tibetan and Chinese traders offer higher prices. The materials are unloaded in steep land at the bank of Arun river on the Nepal side, and are temporarily stored in the tent warehouse for two to three days. Due to the lack of proper storage, rain and theft are major problems. Yak and other animals may also feed on them. After contacting the Tibetan/Chinese party, the bundles are transported to Changa Bazar, Tibet by ropeways above the Arun river, the border between Nepal and China. They are transported in vehicles to Ri'og and beyond. Often, the Tibetan/Chinese traders complain about wet materials, and bargain for lower prices. The Bhotiya traders are advocating for the local Authority of Nepal government to establish a better systematic store/warehouse in Kimathanka.

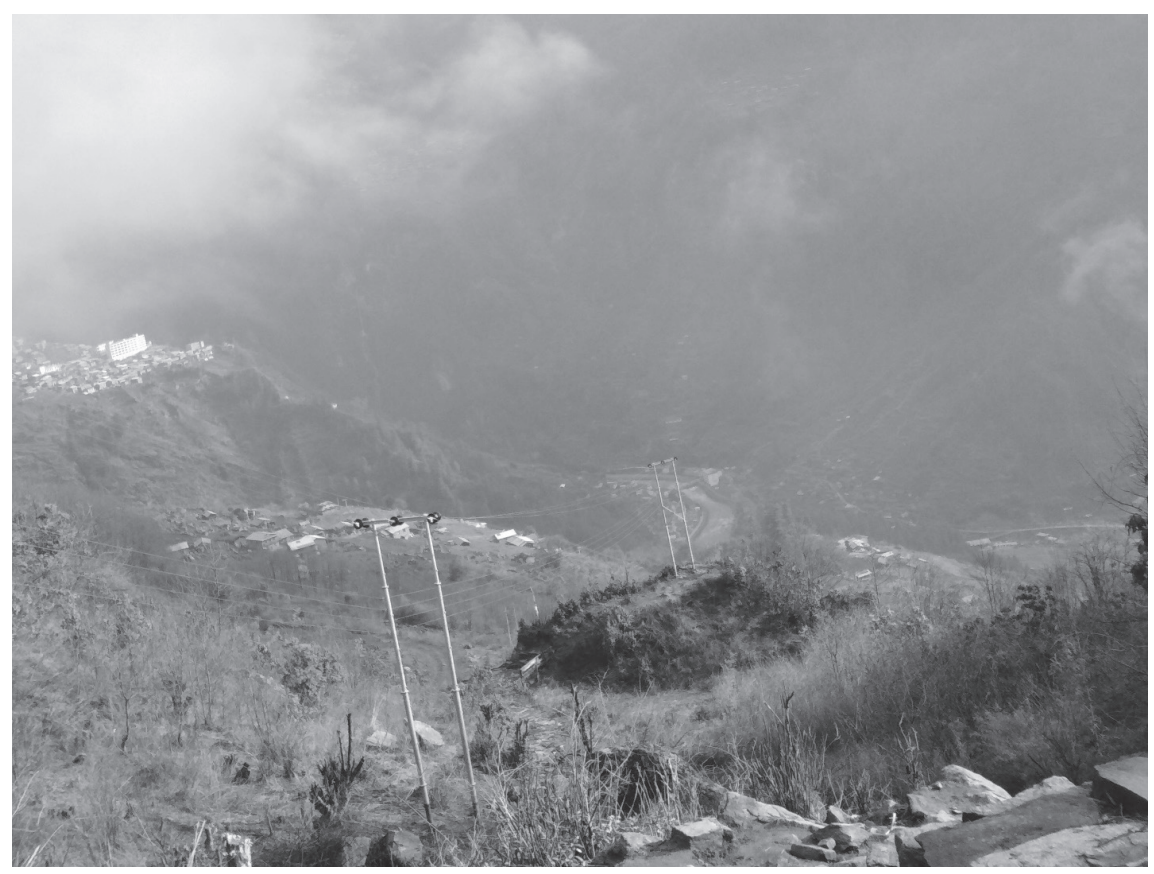

Figure 12: Tibet border market Changa Bazaar in the bank of Arun river and Chentang (with municipal office) in the uphill, across Kimathanka, Nepal. Before the road construction to Changa Bazaar, Bhotiyas used to carry their wares themselves or using yaks to Ri'og. The road was constructed to Changa in 2015. 

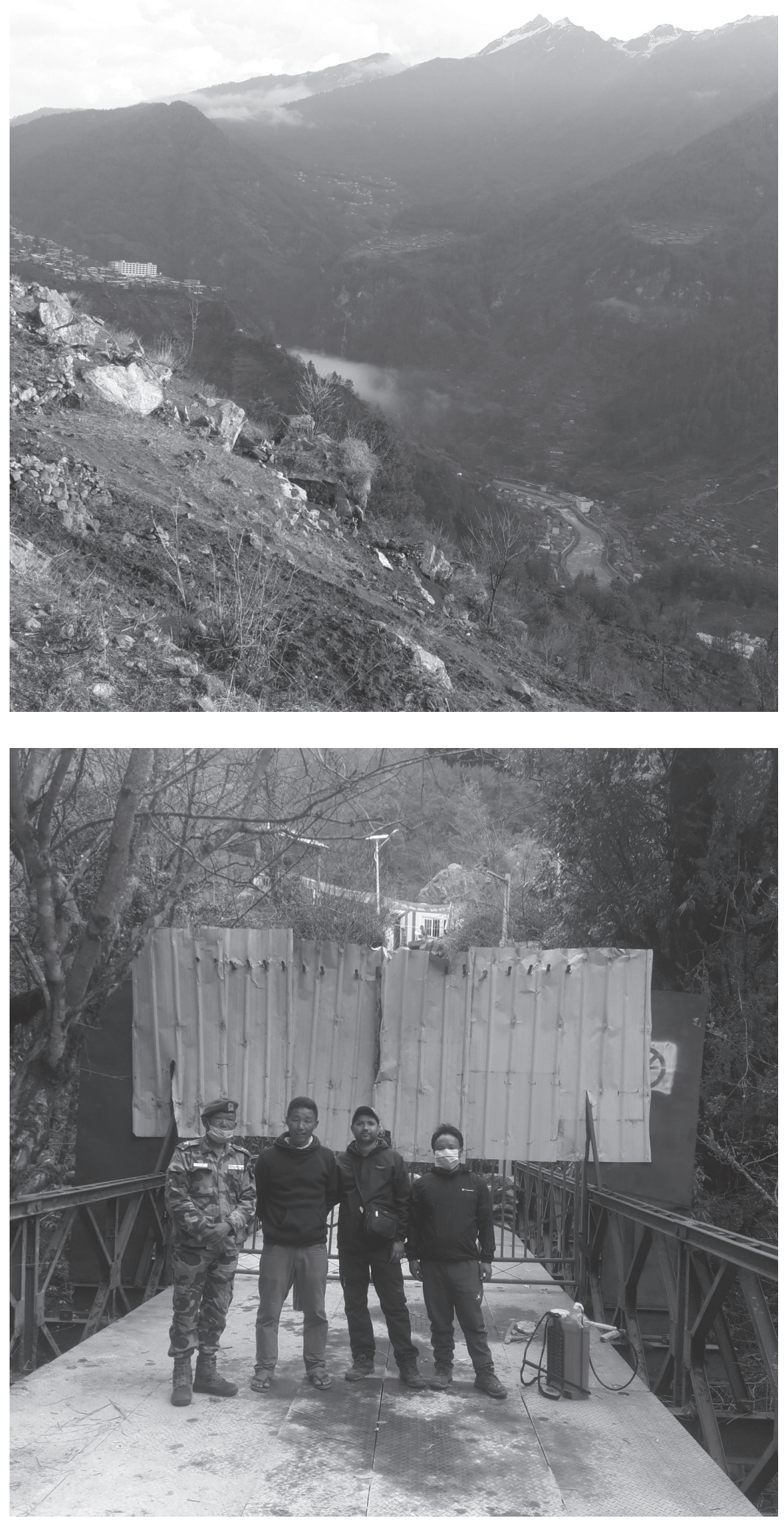

Figure 13: Tibetan Chentang and Chaanga bazaar, view from Kimathanka, Bhotkhola.

Figure 14: Disinfector spray aided by Dinggyê County passed via sealed (due to COVID-19) Kimathanka- Chentang (Nepal-China) border point on Kamuchangu River's gate (Friendship Bridge) on March 27, 2020 along with

representatives of Health worker, Armed Police Force-Inspector Devkumar Rai, and Pala Bhote accompanying by the researcher. The bordered Nepalese Bhotiya people showing their citizenship can get a one day pass to visit and trade in Changa Bazaar and Chentang, Tibet via this border gate.

The border is opened twice a week. Tibetans have not been allowed to enter Nepal since 2008. 
Mr. Arjun Chapagain is pursuing his Ph.D. research at the Department of Public Policy, City University of Hong Kong, supervised by Dr. June Wang. His Ph. D. research is in the regional identity of Tibetan Medicine and transnational trade of Medicinal Plants in the Sino-Nepal trans-border region. He has worked in the field of resource, trade, and market assessment of Non-Timber Forest Products, Medicinal Plants, and livelihood in Nepal Himalayas. This essay was submitted to HIMALAYA in January 2021.

Mr. Pala Bhote works as medicinal plant coordinator at The Upper Arun Valley Development and Conservation Society (UAVDCS) at Sankhuwasabha, Nepal. Before 2008, he had travelled couple of times to Tibetan border market Ri'og in Dinggy County, Tibet to trade Swertia chiarayita and bring back salt and household items.

\section{References}

Bergmann, C. 2016. The Himalayan Border Region: Trade, Identity and Mobility in Kumaon, India. Advances in Asian Human-Environmental Research.

Bhotkhola Rural Municipality https://en.wikipedia.org/ wiki/Bhotkhola

Budathoki, K. 2009. Kimathanka customs office in paper only. The Himalayan Times, Nepal. Published: December 21, 2009 4:59 am On: Nepal. https://thehimalayantimes. com/nepal/kimathanka-customs-office-in-paper-only/ Accessed on 30 May 2020.
Cunningham, A.B., Brinckmann, J.A., Schippmann, U. \& Pyakurel, D. 2018. Production from both wild harvest and cultivation: The cross-border Swertia chirayita (Gentianaceae) trade. Journal of Ethnopharmacology, 225, 42-52.

He J., Yang, B., Dong, M. \& Wang, Y. 2018. Crossing the roof of the world: Trade in medicinal plants from Nepal to China. Journal of Ethnopharmacology, 224, 100-110.

Lewis, C. A. R. H. 2010. Developing the Sacred: Local \& Global Bikas in the Nepali Bhotkhola. Independent Study Project (ISP) Collection. 1237. https://digitalcollections.sit. edu/isp_collection/1237

Phoboo, S. and Jha, P. K. 2010. Trade and Sustainable Conservation of Swertia chirayita (Roxb. ex Fleming) h. Karst in Nepal. Nepal Journal of Science and Technology, 11, 125-132. DOI: https://doi.org/10.3126/njst.v11i0.4134

TMI. 2016. The Mountain Institute's Medicinal and Aromatic Plants Program: Improving livelihoods in Nepal's rural mountain communities since 2001. http://mountain. org/medicinal-aromatic-plants-program/ archieved on 30 May 2020, 1:25 AM.

Sankhuwasabha Senior Citizens Voice (Social-Original Hisory). 2020. Pathakdhara Tole Bikas Sanstha. Khandbaari 1, Sankhuwasaba) Page 731-732. In Nepali. 